Research Article

\title{
Female Sexual Function at Three Months Post-delivery in Spontaneous Labor and Cesarean Section
}

\author{
Fungsi Seksual Perempuan pada Tiga Bulan Pascapersalinan Spontan dan Seksio Sesarea
}

\author{
Suntoro, I Putu G Kayika \\ Department of Obstetrics and Gynecology \\ Faculty of Medicine University of Indonesial \\ Dr. Cipto Mangunkusumo Hospital \\ Jakarta
}

\begin{abstract}
Objective: To study the comparison of encouragement, stimuli, orgasm, pain and satisfaction of female sexual function at 3 months postpartum between spontaneous delivery and cesarean section in Dr. Cipto Mangunkusumo Hospital in Jakarta.
\end{abstract}

Method: This was an observational research, sexual function was measured at three months post-delivery with Female Sexual Function Index (FSFI) questionnaire. The study design used was cross sectional with consecutive sampling. Analysis for comparative nonpaired categorical variables was done using Chi square or Fisher analysis. Analysis for confounding variables was carried out using multivariate logistic regression.

Result: From 150 respondents, $43.3 \%$ had sexual dysfunction, with $52 \%$ of the spontaneous labor group and $34 \%$ of the cesarean section group. Bivariate analysis showed that occurrence of sexual dysfunction at three months post-spontaneous labor was 1.5 times higher (95\% CI 1.02-3.19) compared with cesarean section. Sexual encouragement shows a two-fold difference (95\% CI 1.17-3.40) compared to cesarean section. However, orgasm disturbance was 8 times higher $(95 \%$ CI 1.90-3.58) in the spontaneous labor group, with confounding variable of perineal rupture. Disturbance of sexual stimuli, satisfaction, and pain were not significantly different between spontaneous labor and cesarean section. Multivariate analysis found that spontaneous labor was statistically significant for sexual dysfunction at three months post-delivery in patients with sexual encouragement $(R R=2.716, p=0.008)$ and orgasm accession dysfunction $(R R=$ $6.952, p=0.031)$. However, the more than 30 years old of age variable was statistically significant in sexual dysfunction variable with $R R=$ 2.60 and $\mathrm{p}=0.021$.

Conclusion: Spontaneous labor is statistically significant for sexual dysfunction at three months post-delivery, especially for sexual encouragement and orgasm accession. Meanwhile, the variables with the age of 30 years old or older of age were influential on sexual dysfunction, especially to the sexual stimuli variable.

[Indones J Obstet Gynecol 2015; 3: 127-132]

Keywords: labor method, sexual dysfunction, three months postdelivery

\begin{abstract}
Abstrak
Tujuan: Mengetabui perbandingan dorongan, bangkitan, orgasme, nyeri dan kepuasan seksual perempuan 3 bulan pascapersalinan pada persalinan spontan dan seksio sesarea di Rumah Sakit Dr. Cipto Mangunkusumo, Jakarta.

Metode: Penelitian ini adalab penelitian observasional, dengan subjek kelompok persalinan spontan dan seksio sesarea, yang dilakukan pengukuran fungsi seksualnya 3 bulan pascapersalinan menggunakan kuesioner Female Sexual Function Index (FSFI), dengan desain penelitian potong lintang dan pengambilan sampel consecutive sampling. Analisis komparatif katagorik tidak berpasangan menggunakan Chi square atau uji Fisher. Analisis variabel perancu dilakukan dengan analisis multivariat regresi logistik.
\end{abstract}

Hasil: Dari 150 responden pascapersalinan spontan dan seksio sesarea didapatkan 43,3\% mengalami disfungsi seksual dengan 52\% kelompok persalinan spontan dan 34\% kelompok seksio sesarea. Analisa bivariat menunjukkan terjadinya disfungsi seksual 3 bulan pascapersalinan spontan 1,5 kali lebih besar (IK 95\% 1,02-3,19) dibandingkan seksio sesarea. Gangguan hasrat/dorongan seksual 2 kali lebib besar (IK 95\% 1,17-3,40) dibandingkan seksio sesarea, sedangkan gangguan orgasme 8 kali lebib besar (IK 95\% 1,90-3,58) dengan variabel perancu yaitu robekan perineum. Gangguan bangkitan seksual, lubrikasi, kepuasan seksual dan nyeri tidak berbeda secara bermakna antara persalinan spontan dan seksio sesarea. Analisa multivariat variabel persalinan spontan bermakna secara statistik untuk disfungsi seksual pasien 3 bulan pascapersalinan pada variabel disfungsi dorongan seksual $(R R=2,716, p=0,008)$ dan pencapaian orgasme $(R R=$ $6,952, p=0,031$ ), sedangkan variabel usia lebih dari 30 tabun bermakna secara statistik pada disfungsi seksual pada variabel bangkitan seksual de$n$ gan $p=0,021$ dan $R R=2,601$.

Kesimpulan: Persalinan spontan bermakna secara statistik untuk terjadinya disfungsi seksual 3 bulan pascapersalinan, terutama untuk variabel dorongan seksual dan tercapainya orgasme. Sedangkan variabel usia lebih dari 30 tabun merupakan variabel yang berpengarub pada disfungsi seksual, terutama pada variabel bangkitan seksual.

[Maj Obstet Ginekol Indones 2015; 3: 127-132]

Kata kunci: disfungsi seksual, metode persalinan, tiga bulan pascapersalinan

Correspondence: Suntoro. Jln. Ciminyak Sobang no 8 RT 001/01 Ds. Ciminyak, Lebak, Banten. Mobile: 0813-19125221

Email: toro94dr@gmail.com

\section{INTRODUCTION}

Changes in women's sexual function after childbirth ranges from $23 \%-86 \%$ and has a significant impact on family harmony. Various studies on female sexual function after childbirth have performed the comparison of diverse variables, among others, by 
Glasner, Barret, Thomson and Rochelle with different results due to different measuring devices, time measurement, and control of confounding variables. Baret et al, in a cross-sectional study in 796 primiparous women for over 6 months, found $62 \%$ had dyspareunia in the first 3 months post-delivery, $31 \%$ at 6 months postdelivery, and $12 \%$ in the first year. Sexual desire disorder was found in $53 \%$ of women in the first 3 months, $37 \%$ at 6 months and $9 \%$ in the first year. As for the disturbance to reach orgasm was identified in $33 \%$ of women in the first 3 months, $23 \%$ within the first 6 months, and 14\% in the first year. ${ }^{1,2-4}$

This study is carried out because there is an absence of data on sexual dysfunction 3 months postdelivery in spontaneous labor and cesarean section in Jakarta and Indonesia, as well as a confirmation of the existing research. We aim to study the comparison of encouragement, stimuli, orgasm, pain and satisfaction of female sexual function at 3 months postpartum between spontaneous delivery and cesarean section in Dr. Cipto Mangunkusumo Hospital in Jakarta.

Table 1. Characteristic of Respondents

\begin{tabular}{|c|c|c|c|c|}
\hline Characteristics & Total $(n=150)$ & Spontaneous $(n=75)$ & C-Section $(n=75)$ & $\mathrm{p}$ \\
\hline Age, Median Cluster of age, $n(\%)$ & $30(25-33)$ & $30(25-35)$ & $31(26-34)$ & 0.211 \\
\hline$<20$ years & $9(6.0)$ & $5(6.7)$ & $4(5.3)$ & 0.210 \\
\hline $20-30$ years & $72(48.0)$ & $42(56.0)$ & $30(40.0)$ & \\
\hline $31-40$ years & $63(42.0)$ & $24(32.0)$ & $39(52.0)$ & \\
\hline$>40$ years & $6(4.0)$ & $4(5.3)$ & $2(2.7)$ & \\
\hline \multicolumn{5}{|l|}{ Level of Education, $\mathbf{n}(\%)$} \\
\hline Elementary & $45(30.0)$ & $22(29.3)$ & $23(30.7)$ & 0.904 \\
\hline Advanced & $81(54.0)$ & $40(53.3)$ & $41(54.7)$ & \\
\hline University/college & $24(16.0)$ & $13(17.3)$ & $11(14.7)$ & \\
\hline \multicolumn{5}{|l|}{ Working Statue, n (\%) } \\
\hline Yes & $94(62.7)$ & $49(65.3)$ & $45(60.0)$ & 0.500 \\
\hline No & $56(37.3)$ & $26(34.7)$ & $30(40.0)$ & \\
\hline \multicolumn{5}{|l|}{ Parity, n (\%) } \\
\hline Primipara & $58(38.7)$ & $29(38.7)$ & $29(38.7)$ & 1.000 \\
\hline Multipara & $87(58.0)$ & $44(58.7)$ & $43(57.3)$ & \\
\hline Grande multipara & $5(3.3)$ & $2(2.7)$ & $3(4.0)$ & \\
\hline Average Baby Weight (gr) & 2900 & 3020 & 2800 & 0.026 \\
\hline Baby Weight Range & $(2600-3200)$ & $(2800-3250)$ & $(2600-3100)$ & \\
\hline \multicolumn{5}{|l|}{ Cluster Baby weight, n (\%) } \\
\hline$<2500$ gram & $14(9.3)$ & $7(9.3)$ & $7(9.3)$ & 1.000 \\
\hline $2500-4000$ gram & $132(88.0)$ & $67(89.3)$ & $65(86.7)$ & \\
\hline$>4000$ gram & $4(2.7)$ & $1(1.3)$ & $3(4.0)$ & \\
\hline \multicolumn{5}{|l|}{ Perineal Tear Degree } \\
\hline No Tear & $93(62.0)$ & $18(12.0)$ & $75(0.0)$ & $<0.001$ \\
\hline Grade I (Light) & $7(4.7)$ & $7(4.7)$ & $0(0.0)$ & \\
\hline Grade II (Moderate) & $43(28.7)$ & $43(28.7)$ & $0(0.0)$ & \\
\hline Grade III-IV (Heavy) & $7(4.7)$ & $7(4.7)$ & $0(0.0)$ & \\
\hline \multicolumn{5}{|l|}{ Breastfeeding Status } \\
\hline Yes & $130(86.6)$ & $62(82.7)$ & $68(90.7)$ & $<0.001$ \\
\hline No & $20(13.3)$ & $13(17.3)$ & $7(9.3)$ & \\
\hline \multicolumn{5}{|l|}{ Start of Sexual Intercourse } \\
\hline Within 40 day & $138(92.0)$ & $69(92.0)$ & $69(92.0)$ & 1.000 \\
\hline 2 months & $6(4.0)$ & $4(5.3)$ & $2(2.7)$ & \\
\hline 3 months & $6(4.0)$ & $2(2.7)$ & $4(5.3)$ & \\
\hline
\end{tabular}




\section{METHOD}

We carried out an observational study measuring sexual function 3 months post-delivery using the Female Sexual Function Index (FSFI) questionnaire, with a cross-sectional study design and consecutive sampling.

Analysis for post-delivery female sexual function based on the method of delivery (spontaneous labor or cesarean section) was carried out using Chisquare or Fisher test. Analysis of confounding variables (parity, age, education, parity and degree of perineal laceration) was done by multivariate logistic regression.

\section{RESULT}

We included 150 subjects in our study, 75 subjects in each group of spontaneous labor and cesarean section. The characteristics of our respondents are presented in Table 1.

From 150 respondents, $43.3 \%$ had sexual dysfunction, with $52 \%$ of the spontaneous labor group and $34 \%$ of the cesarean section group. Bivariate analysis showed that occurrence of sexual dysfunction at three months post-spontaneous labor was 1.5 times higher (95\% CI 1.02-3.19) compared with cesarean section. Sexual encouragement shows a two-fold difference (95\% CI 1.17-3.40) compared to cesarean section. However, orgasm disturbance was 8 times higher (95\% CI 1.90-3.58) in the spontaneous labor group, with confounding variable of perineal rupture. Disturbance of sexual stimuli, satisfaction, and pain were not significantly different between spontaneous labor and cesarean section.

Table 2. The Relationship between Sexual Dysfunction and Various Variables

\begin{tabular}{|c|c|c|c|c|c|c|c|}
\hline \multicolumn{8}{|c|}{ Sexual Function } \\
\hline \multirow{2}{*}{ Variables } & \multicolumn{2}{|c|}{ Dysfunction } & \multicolumn{2}{|c|}{ Normal } & \multirow{2}{*}{$\mathrm{p}$} & \multirow{2}{*}{$\mathrm{RR}$} & \multirow{2}{*}{$95 \% \mathrm{CI}$} \\
\hline & $\mathbf{N}$ & $\%$ & $\mathbf{N}$ & $\%$ & & & \\
\hline \multicolumn{8}{|l|}{ Mode of Delivery } \\
\hline Spontaneous labor & 39 & 52.0 & 36 & 48.0 & 0.032 & 1.500 & $1.027-2.192$ \\
\hline Cesarean section & 26 & 34.7 & 49 & 65.3 & & & \\
\hline \multicolumn{8}{|l|}{ Age } \\
\hline$<20$ year & 2 & 22.2 & 7 & 77.8 & 0.716 & 0.934 & $0.648-1.374$ \\
\hline 20-30 year & 32 & 44.4 & 40 & 55.6 & & & \\
\hline $31-40$ year & 27 & 42.9 & 36 & 57.1 & & & \\
\hline$>40$ year & 4 & 66.7 & 2 & 33.3 & & & \\
\hline \multicolumn{8}{|l|}{ Education Level } \\
\hline Elementary & 21 & 46.7 & 24 & 53.3 & 0.590 & 1.114 & $0.758-1.637$ \\
\hline Advanced & 35 & 43.2 & 46 & 56.8 & & & \\
\hline University & 9 & 37.5 & 15 & 62.5 & & & \\
\hline \multicolumn{8}{|l|}{ Parity } \\
\hline Primipara & 24 & 41.4 & 34 & 58.6 & 0.701 & 0.929 & $0.634-1.360$ \\
\hline Multipara (2-4) & 36 & 41.4 & 51 & 58.6 & & & \\
\hline Grande Multipara ( $\geq 5$ ) & 5 & 100.0 & 0 & 0.0 & & & \\
\hline \multicolumn{8}{|l|}{ Perineal Tear Degree } \\
\hline No tear & 37 & 39.8 & 56 & 60.2 & 0.415 & 0.854 & $0.589-1.239$ \\
\hline Light & 4 & 57.1 & 3 & 42.9 & & & \\
\hline Moderate & 21 & 48.8 & 22 & 51.2 & & & \\
\hline Severe & 3 & 42.9 & 4 & 57.1 & & & \\
\hline \multicolumn{8}{|l|}{ Breast Feeding } \\
\hline Yes & 58 & 44.6 & 72 & 55.4 & 0.419 & 1.275 & $0.681-2.387$ \\
\hline No & 7 & 35.0 & 13 & 65.0 & & & \\
\hline
\end{tabular}


Table 3. Multivariate Analysis of Factors that Affect Sexual Desire Dysfunction

\begin{tabular}{lcccccc}
\hline \hline \multicolumn{1}{c}{ Variables } & B & S & E Wald & p-value & R & 95\% CI \\
\hline Spontaneous Delivery & 0.999 & 0.377 & 7.041 & 0.008 & 2.716 & $1.298-5.682$ \\
Multiparity & 0.643 & 0.393 & 2.681 & 0.102 & 1.903 & $0.881-4.111$ \\
Constant & -1.810 & 0.401 & 20.352 & $<0.001$ & 0.164 & \\
\hline \hline
\end{tabular}

Multivariate analysis found that spontaneous labor was statistically significant for sexual dysfunction at three months post-delivery in patients with sexual encouragement $(R R=2.716, p=0.008)$ and orgasm accession dysfunction $(R R=6.952, p=0.031)$. However, the more than 30 years old of age variable was statistically significant in sexual dysfunction variable with $\mathrm{RR}=2.60$ and $\mathrm{p}=0.021$.

\section{DISCUSSION}

Spontaneous labor often have complications such as laceration of the birth canal, and is considered to affect the occurrence of post-delivery sexual dysfunction compared to cesarean section. ${ }^{5}$ The comparative data on the presence of female sexual function 3 months post-delivery with spontaneous labor and cesarean section in Indonesia in detail, with control of confounding variables and adequate number of samples are the advantages of this study, while the drawback is the collection of data by telephone interview resulting in a lack of data accuracy and the possibility of bias. Most respondents (92\%) have resumed sexual activity at 40 days post-delivery, only $4 \%$ who had sexual intercourse with her partner after 2 months post-delivery by reason of fear of pain because of the IUD, perineal sutures on spontaneous labor, as well as the fear of opening the surgical wounds in cesarean section. This is consistent with the Barret study, which found that $89 \%$ of women have begun sexual activity at three months post-delivery, and there was no significant difference in the return of sexual relationship between cesarean section with spontaneous labor. ${ }^{6}$ The reasons given for delaying sexual intercourse are concern about perineal pain, bleeding and fatigue.

The best suggestion regarding when to start intercourse is based on the desire and comfort of the patient. ${ }^{2}$ Three months post-delivery, $43.3 \%$ experienced sexual dysfunction with a ratio of $52 \%$ in spontaneous delivery and $34 \%$ in cesarean section. With the highest domain being sexual desire (40\%) in spontaneous labor and pain during sexual inter- course $(24 \%)$ in the cesarean section, followed by sexual arousal dysfunction, orgasm, lubrication, and sexual satisfaction. Buhling et al, in a cross-sectional study in 796 primiparous women for over 6 months, found $62 \%$ had dyspareunia in the first 3 months post-delivery, $31 \%$ at 6 months post-delivery, $12 \%$ in the first year. For sexual desire disorder, it was obtained that $53 \%$ had experienced this in the first 3 months, $37 \%$ at 6 months and $9 \%$ in the first year. It was also found that $33 \%$ experienced disturbance to reach orgasm in the first 3 months, $23 \%$ within the 6 months, and $14 \%$ in the first year. ${ }^{1,7}$ Postdelivery sexual function can be affected by several factors, such as injury to the perineum, pudendal neuropathy, vaginal dryness due to breastfeeding, to changes in relationships, function and lifestyle. It is widely reported that mode of delivery affect postdelivery sexual function, with the incidence of injury to the birth canal in vaginal delivery said to be one of the main factors of sexual dysfunction postdelivery. ${ }^{3}$ In bivariate analysis, disruptions of sexual desire in 3 months post-spontaneous delivery was 2 times greater (95\%CI 1.17-3.40) compared to cesarean section, while disruption of orgasm was 8 times greater (95\%CI 1.90-3.58) with the presence of perineal laceration as confounding variable. Sexual dysfunction at 3 months post-spontaneous delivery has been found to be 1.5 times greater $(95 \% \mathrm{CI}$ 1.02-2.19) compared to cesarean section.

In theory, sexual desire disorder is a spectrum of disease that causes personal suffering due to loss of sexual fantasies and desire that persists or recurs, and the lack of response to sexual activity. This condition can be caused by menopause due to medical reasons, depression, endocrine disorders, prolonged conflict, psychological or emotional problems, childhood trauma, and physical or sexual abuse. Sexual arousal disorder is the persistent or recurrent inability to obtain or maintain adequate sexual pleasure, lack of subjective pleasure, lack of somatic responses, lack of genital lubrication or swelling, which may be caused by nerve damage after surgery, organic causes in the pelvic area which may decrease 
sensation in the labia and clitoris, as well as lack of vaginal smooth muscle relaxation. Other causes are generally psychological. Disorders of orgasm may be complete loss or recurrent difficulty in achieving orgasm after sufficient stimulation, usually caused by emotional trauma or sexual abuse, hormone deficiency, trauma due to surgery, or treatment using SSRIs (selective serotonin reuptake inhibitors). ${ }^{3,8}$

At the age of more than 40 years old, is the perimenopausal period; the period in which changes occur in the organs involved in the acceptance of sexual stimulation. Decreased activity of the sweat and oil glands results in decreased touch sensation, while a decrease in fat leads to less optimal breast engorgement and nipple erection in response to sexual stimulation. In addition, the vagina shortens and loses its elasticity, physiological secretion of mucus (lubrication) of the wall of the vagina and cervix is decreased. $3,9,10$ In this study, it was found that age is significantly associated with the sexual generation, where increasing age is related with decreased sexual desire $(R R=0.52)$.

Fajewonyomi et al discovered that sexual dysfunction is more commonly experienced by Nigerian women with higher levels of education, with the explanation that women with higher education levels have higher awareness regarding health issues and more open in discussing sexual issues. ${ }^{4}$ In this study, education level is associated with impaired lubrication, where the education level is inversely related with the presence of lubrication disorders $(\mathrm{R} R=2.33)$. In contradiction, Rosen et al observed that higher education levels is associated with a lower incidence of sexual dysfunction. ${ }^{8}$

Number of parity and degree of perineal tear are associated with pelvic floor muscle function, which affects the onset of sexual dysfunction after delivery. ${ }^{5,9}$ In this study, parity was not statistically correlated to sexual function, whereas degree of perineal laceration influences orgasm disorder, where the degree of perineal laceration is inversely related to orgasm disorder $(R R=0.25)$. Signorello observed that, in the United States, second-degree perineal laceration, with or without episiotomy, increases the incidence of dyspareunia at 3 months post-delivery. Meanwhile, Rogers et al discovered that in labor with spontaneous birth canal injury (without episiotomy), there is no difference in terms of sexual activity and short-term post-delivery sexual function at a low degree perineal laceration (without trauma to degree I) as well as a high degree (degree II-IV). ${ }^{5}$
Breastfeeding is one of the factors that play a role in the occurrence of post-delivery sexual dysfunction. High levels of prolactin cause the levels of estrogen, progesterone and androgens to be decreased, resulting in a decrease of vaginal secretions and the tendency for depressive mood. This can cause sexual pain disorder and lack of interest or sexual desire, as stated by Masters and Johnson. ${ }^{11}$ Actively lactating women have high levels of sexual activity and higher desire to be sexually active, due to the increase in breast eroticism and baby sucking activity. On the other hand, lower sexual activity may be experienced due to breast pain, post-delivery pain, decreased secretion of breast milk and vaginal discharge. In this study, breastfeeding variable was not significantly associated with the occurrence of sexual dysfunction. ${ }^{12}$

Multivariate analysis found that spontaneous labor was statistically significant with the occurrence of sexual dysfunction 3 months post-delivery in sexual arousal dysfunction and achieving orgasm variables, with $\mathrm{p}=0.008$ and $\mathrm{p}=2.716$, while the variable of age being over 30 years old is a significant confounding variable in the occurrence of sexual dysfunction in sexual desire variables $(p=0.021)$. Spontaneous labor variables and age over 30 years are statistically influential variables on sexual dysfunction 3 months post-delivery, whereas the other variables either cesarean section, breastfeeding, working or not, the level of education and degree of perineal laceration was not statistically significant for sexual function. Kapllan stated that women's sexual response is much more complex, involving social, psychological, neurological, vascular and hormonal factors, as well as its interaction with sexual stimulation, central and peripheral nervous systems not being fully understood yet. WHO defines sexual health as the integration of somatic, emotional, intellectual and social aspects in ways that enrich and add to the quality of personality, communication and love. ${ }^{13}$

\section{CONCLUSION}

Almost all respondents have resumed sexual activity at 40 days post-delivery with spontaneous labor or cesarean section, and only few have not started their sexual activity after 3 months post-delivery. The prevalence of sexual dysfunction 3 months post-delivery was $52 \%$ in spontaneous labor and $34 \%$ in cesarean section, with the highest domain in sexual arousal, pain during sexual intercourse, sexual desire, 
lubrication, orgasm disorders, and sexual satisfaction. In spontaneous labor, sexual dysfunction, sexual desire disorder, orgasm disturbances at 3 months post-delivery is greater in spontaneous labor compared to cesarean section, with the presence of perineal laceration as confounding variable. Multivariate analysis of spontaneous labor variable was statistically significant for sexual dysfunction in patients 3 months post-delivery for sexual arousal dysfunction and achieving orgasm variables, while the over 30 years of age variable was significantly influential to the sexual dysfunction variable.

Counseling is required for women, considering the high prevalence of post-delivery sexual dysfunction at 3 months post-delivery. To reduce sampling bias research should be done by direct interviews or home visits, as well as the variable of cesarean section should include patient having elective cesarean.

\section{REFERENCES}

1. Solana-Arellano E, Villegas-Arrizon A, Legorreta-Soberanis J, et al. Women's dispareunia after childbirth: a case study in a hospital in Acapulco, Mexico. Rev Panam Salud Publica 2008; 23(1): 44-51.

2. Glazener CMA. Sexual function after childbirth: women's experiences, persistent morbidity and lack of professional recognition. Br J Obstet Gynaecol 1997; 104: 330-5.

3. Kammerer-Doak D, Rogers RG. Female sexual function and dysfunction. Obstet Gynecol Clin N Am 2008; 35: 169-83.
4. Fajewonyomi BA, Orji EO, Adeyemo AO. Sexual dysfunction among female patients of reproductive age in a hospital setting in Nigeria. J Health Popul Nutr 2007; 25(1): 101-6.

5. Rogers RG, Borders N, Leeman LM, et al. Does spontaneous genital tract trauma impact pascapartum sexual function? J Midwifery Womens Health 2009; 54(2): 98103.

6. Morof D, Barrett G, Peacock J, et al. Postnatal depression and sexual health after childbirth. Obstet Gynecol 2003; 102(6): 1318-25.

7. Buhling KJ, Schmidt S, Robinson JN, et al. Rate of dispareunia after delivery in primiparae according to mode of delivery. Eur J Obstet Gynecol Reprod Biol 2006; 124(1): 42-6.

8. Laumann EO, Paik A, Rosen RC. Sexual dysfunction in the United States: prevalence and predictors. J Am Med Assoc 1999; 281: 537-44.

9. Khajehei M, Ziyadlou S, Safari RM, et al. A comparison of sexual outcomes in primiparous women experiencing vaginal and caesarean births. Indian J Community Med 2009; 34(2): 126-30.

10. Raina R, Pahlajani G, Khan S, et al. Female sexual dysfunction: classification, pathophysiology, and management. Fertil Steril 2007; 88(5): 1273-84.

11. Rowland M, Foxcroft L, Hopman WM, et al. Breastfeeding and sexuality immediately post partum. Can Fam Physician 2005; 51: 1366-7.

12. Ellis DJ, Hewat RJ. Mothers postdelivery perception of spousal relationships, JOGNN 1985; 14: 140-6.

13. Hayes R, Dennerstein L. The impact of aging on sexual function and sexual dysfunction in women: a review of population-based studies. J Sex Med 2005; 2(3): 317-30. 